\title{
PENJADWALAN PRODUKSI MENGGUNAKAN ALGORITMA JADWAL NON DELAY UNTUK MEMINIMALKAN MAKESPAN STUDI KASUS DI CV. BIMA MEBEL
}

\author{
Setyo Harto, Annisa Kesy Garside, dan Dana Marsetya Utama \\ Jurusan Teknik Industri \\ Universitas Muhammadiyah Malang \\ Kampus III UMM JL. Tlogomas Malang \\ Setyoharto042@gmail.Com, annisa_garside@yahoo.com,fund.1986@gmail.com
}

\begin{abstract}
Abstrak
CV. Mebel Bima merupakan sebuah perusahaan yang bergerak dalam bidang pengerjaan kayu khususnya pembuatan berbagai model daun pintu dan kusen. Tipe aliran produksi di perusaaan adalah job shop dikarenakan pengerjaan setiap job memiliki aliran yang berbeda di setiap mesinnya. Penjadwalan produksi di perusahaan adalah diurutkan berdasarkan total waktu penyelesaian job terlama sampai yang terkecil. Permasalahan di perusahaan selama ini adalah besarnya makespan yang dihasilkan oleh penjadwalan dengan metode perusahaan sehingga perusahaan mengalami keterlambatan penyelesaian job dari waktu yang sudah ditetapkan sebelumnya. Berdasarkan masalah tersebut penelitian ini bertujuan untuk menentukan urutan pengerjaan job dengan makespan yang lebih kecil menggunakan algoritma jadwal non delay dengan prioritas SPT. Tahap-tahap dalam penelitian ini adalah dimulai dari observasi langsung di perusahaan, studi literatur, perumusan masalah, pengambilan data, pengolahan data, dan terakhir adalah pembandingan hasil penjadwalan. Metode penjadwalan produksi yang digunakan di perusahaan menghasilkan makespan sebesar 194,4 jam atau 25 hari kerja (1 hari terdapat 8 jam kerja), sedangkan usulan penjadwalan dengan menggunakan algoritma jadwal non delay menghasilkan makespan sebesar 168,79 jam atau 22 hari kerja, dengan demikian Penjadwalan dengan menggunakan algoritma jadwal non delay dapat menghemat total waktu pengerjaan sebesar 24,85 jam atau 3 hari kerja lebih 0,85 jam.
\end{abstract}

Kata kunci : Non delay, job shop, penjadwalan produksi, penjadwalan mesin.

\section{PENDAHULUAN}

CV Mebel Bima merupakan sebuah perusahaan manufaktur yang bergerak dalam bidang pengerjaan kayu yang berlokasi di Kota Malang. Produk yang dibuat di perusahaan adalah daun pintu dan kusen. Aliran proses produksi di perusahaan bertipe job shop yaitu setiap produk dalam penyelesaiannya melalui proses yang berbeda di setiap operasi dan dilihat dari tipe produksinya perusahaan bertipe make to order yaitu ketika ada pemesanan baru melakukan aktifitas produksi. Konsumen dari perusahan adalah perorangan, pesanan dari toko furniture, maupun proyek perumahan yang biasanya memesan produk dalam jumlah yang besar. Perusahaan dalam memenuhi pesanan memiliki 14 karyawan tetap yang masing masing ditempatkan di work center yang ada. Bahan baku utama produksi yaitu kayu didapatkan dari wilayah sekitar Kabupaten Malang, Lumajang, dan Probolinggo sedangkan bahan pendukung didapatkan dari Kota Malang.

Selama ini perusahaan dalam menentukan urutan pengerjaan job berdasarkan total waktu pengerjaan job terlama sampai terkecil. Penjadwalan dengan metode tersebut menimbulkan masalah bagi perusahaan antara lain penyelesaian job seringkali melebihi waktu yang ditargetkan oleh perusahaan. Besarnya makespan menyebabkan bertambahnya waktu produksi perusahaan, sehingga perusahaan terlambat untuk memulai produksi pada order bulan selanjutnya. Seperti yang terjadi pada bulan September 2014 perusahaan mengalami keterlambatan untuk memulai produksi karena job yang seharusnya sudah selesai terlambat dua hari dari yang sudah ditetapkan perusahaan.

Menurut [1], usulan penjadwalan produksi dengan menggunakan algoritma jadwal Non delay dapat meminimasi makespan sebesar 55,54 \% dari total makespan dengan penjadwalan produksi yang digunakan oleh perusahaan sebelumnya. Algoritma jadwal non 
delay diharapkan dapat memberikan usulan penjawalan yang lebih baik dari metode penjadwalan yang digunakan oleh perusahaan sebelumnya, dengan demikian perusahaan dapat menyelesaikan pekerjaan yang datang di awal bulan sesuai target yang telah ditetapkan.

\section{LANDASAN TEORI}

\section{A. Penjadwalan Job Shop}

Menurut [2], Pada aliran job shop dicirikan masing-masing job memiliki urutan proses operasi yang unik. Setiap job bergerak dari satu mesin/stasiun kerja menuju mesin/stasiun kerja lainnya dengan pola yang random. Lintasan prosesnya dapat dilihat pada Gambar 1.

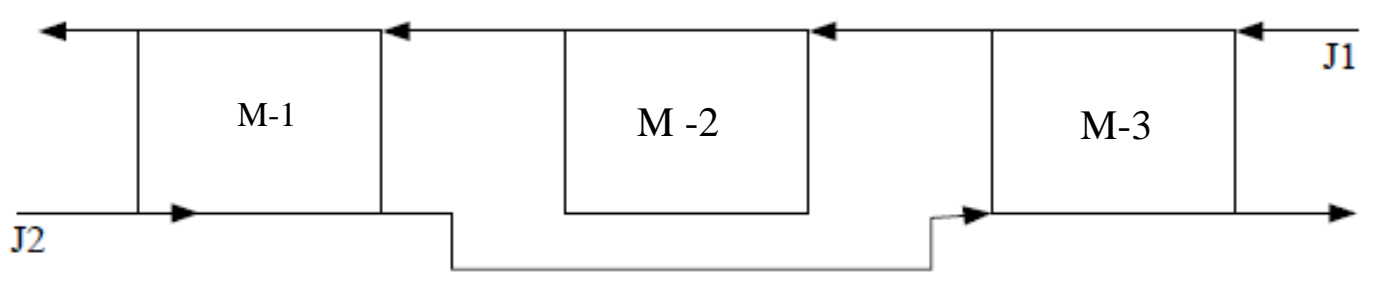

Gambar 1. Pola aliran job shop

\section{B. Terminologi dalam Penjadwalan Job Shop}

Beberapa istilah dalam penjadwalan adalah sebagai berikut :

1. Processing time $\left(t_{i}\right)$

Adalah waktu yang dibutuhkan untuk mengerjakan suatu pekerjaan. Dalam waktu proses ini sudah termasuk waktu yang dibutuhkan untuk persiapan dan pengaturan (set-up) selama proses berlangsung.

2. Due-date $\left(D_{t}\right)$

Adalah batas waktu dimana operasi terakhir dari suatu pekerjaan harus selesai.

3. Slack time $\left(S L_{i}\right)$

Adalah waktu yang tersisa akibat dari waktu prosesnya lebih kecil dari duedate-nya.

4. Flow time $\left(F_{i}\right)$

Flow time, rentang waktu antara satu titik dimana tugas tersedia untuk diproses dengan suatu titik ketika tugas tersebut selesai. Jadi, flow time sama dengan processing time dijumlahkan dengan waktu ketika tugas menunggu sebelum diproses.

5. Completion time $\left(C_{i}\right)$

Adalah waktu yang dibutuhkan untuk menyelesaikan mulai dari saat tersedianya pekerjaan $(\mathrm{t}=0)$ sampai pada pekerjaan tersebut selesai.

6. Lateness $\left(L_{i}\right)$

Adalah selisih antara completion time $\left(C_{i}\right)$ dengan due date-nya $\left(D_{t}\right)$. Suatu pekerjaan memiliki lateness yang bernilai positf apabila pekerjaan tersebut diselesaikan setelah due date-nya, pekerjaan tersebut akan memiliki keterlambatan yang negative. Sebaliknya jika pekerjaan diselesaikan setelah batas waktunya, pekerjaan tersebut memiliki keterlambatan yang positif.

7. Tardiness $\left(T_{i}\right)$

Adalah ukuran waktu terlambat yang bernilai positif jika suatu pekerjaan dapat diselesaikan lebih cepat dari due date-nya.

Tardiness $\geq 0$

8. Makespan (M)

Adalah total waktu penyelesaian pekerjaan-pekerjaan mulai dari urutan pertama yang dikerjakan pada work center pertama sampai kepada urutan pekerjaan terakhir pada work center terakhir. 


\section{Algoritma Jadwal Non-delay}

Menurut [3], metode penjadwalan non Delay adalah metode penjadwalan aktif yang tidak membiarkan mesin menjadi idle bila suatu operasi dapat dimulai. Tahapantahapan dalam algoritma penjadwalan non delay dengan menambahkan heuristik dispatching rule SPT (shortest prosesing time) sebagai aturan prioritas adalah sebagai berikut:

1. Step 1: $k=0$, PS $(k)=0$, Set $S(k)$ sama dengan seluruh operasi tanpa pendahulu.

2. Step 2 : tentukan $S^{*}=\min \mathrm{j} € S_{k}\left\{S_{j}\right\}$ dimana $S_{j}$ adalah saat paling awal j dapat mulai dikerjakan. tentukan $m^{*}$ yaitu mesin dimana $S^{*}$ dapat direalisasi.

3. Step 3: untuk setiap operasi dalam $\mathrm{j} € \mathrm{~S}(k)$ yang memerlukan mesin $m^{*}$ dapat memiliki $S_{j}<S^{*}$, hitung sebuah indeks prioritas berdasarkan aturan prioritas SPT. Tentukan operasi dengan indeks prioritas yang terkecil dan tambahkan operasi tersebut ke dalam PS $(k)$ sehingga terbentuk hanya satu jadwal parsial, PS $(\mathrm{k}+1)$, untuk tahap berikutnya.

4. Step 4 : untuk setiap jadwal parsial baru PS $(\mathrm{k}+1)$, yang telah dihasilkan dari step 3 , perbarui set data tersebut.

- Keluarkan operasi j dari $\mathrm{Sk}$

- $\quad$ Bentuk $S(k+1)$ dengan menambahkan suksesor langsung dari operasi j

- $\quad$ Naikan nilai $k$ dengan 1

5. Step 5 : kembali ke step 2 untuk tiap jadwal parsial yang dihasilkan pada step 3 dan perbarui pada step 4. Lanjutkan langkah langkah ini sampai seluruh jadwal non delay dhasilkan.

Dimana :

PS $k$ : jadwal parsial yang terdiri dari $k$ operasi terjadwal

$\mathrm{S}(k)$ : set operasi yang bisa dijadwalkan pada stage $k$, Setelah diperoleh PS $k$

$\mathrm{S} j$ : saat operasi paling awal dimana operasi $\mathrm{j} € \mathrm{~S}(k)$ dapat dimulai

$\mathrm{fj} \quad$ : saat paling awal dimana operasi $\mathrm{j} € \mathrm{~S}(k)$ dpat diselesaikan

\section{III.METODOLOGI PENELITIAN}

Langkah-langkah dalam penelitian ini sesuai urutan sebagai berikut:

\section{A. Survey Perusahaan}

Survey perusahaan dilakukan untuk mengetahui kondisi nyata yang terjadi di perusahaan, Dalam hal ini yang diamati adalah alur produksi, kendala-kendala yang terjadi di perusahaan dan segmentasi konsumen.

\section{B. Studi Literatur}

Studi literatur dilakukan untuk memahami proses-proses yang terjadi dalam industri manufaktur dan metode penyelesaian masalahnya.

\section{Perumusan Masalah}

Langkah pertama dalam merumuskan masalah yang perlu diketahui adalah kendala yang terjadi dalam perusahaan serta efek yang terjadi ketika kendala itu muncul. selanjutnya menentukan kriteria permasalahan untuk mencari metode apa yang digunakan. Selama penelitian ini masalah yang terjadi dalam perusahaan adalah keterlambatan proses produksi melebihi target yang ditentukan oleh perusahaan. Kriteria penjadwalanya adalah bertipe job shop sehingga metode yang digunakan adalah algoritma untuk penjadwalan job shop untuk meminimalkan makespan.

\section{Pengumpulan Data}

Setelah perumusan masalah langkah selanjutnya yang perlu dilakukan adalah mengambil data yang diperlukan untuk menyelesaikan permasalahan tersebut, dalam hal ini adalah data-data yang diperlukan untuk penjadwalan produksi. Data-data yang diperlukan adalah sebagai berikut : 
a. Data order pada bulan Desember 2014.

Data order pada bulan Desember 2014 meliputi jenis produk yang dipesan, jumlah pesan, dan tanggal pemesanan.

b. Struktur produk.

Struktur produk dalam hal ini adalah komponen apa saja yang dibutuhkan untuk membentuk satu produk jadi yang dipesan pada bulan Desember 2014.

c. Urutan proses tiap komponen

Tahap ini peneliti melakukan pencatatan urutan permesinan dalam memproses komponen yang dibuat untuk memenuhi pesanan bulan Desember 2014.

d. pengukuran waktu pada tiap operasi pengukuran waktu yang dilakukan dalam penelitian ini menggunakan pengukuran langsung dengan metode stopwatch time study.

\section{E. Pengolahan Data}

Setelah mendapatkan data waktu pada tiap operasi selanjutnya dilakukan pengolahan data dengan langkah sebagai berikut :

a. Uji keseragaman data.

Data waktu operasi dari hasil pengamatan selanjutnya dilakukan uji keseragaman data, dalam penelitian ini menggunakan tingkat kepercayaan $95 \%=2$

b. Uji kecukupan data

Dalam uji kecukapan data tingkat kepercayaan yang digunakan adalah $95 \%=2$, sedangkan tingkat ketelitian adalah $5 \%=0,05$.

c. Menghitung waktu baku.

Perhitungan waktu baku, langkah pertama yang dilakukan adalah menentukan waktu siklus, selanjutnya menentukan waktu normal dengan penyesuaian menggunakan metode westing house, selanjutnya menentukan waktu baku dari hasil perhitungan waktu normal ditambah allowance yang diberikan.

d. Menghitung total kebutuhan komponen.

Total kebutuhan komponen dihitung dari jumlah kebutuhan komponen untuk membentuk 1 produk jadi dikalikan jumlah pesanan produk tersebut pada bulan Desember 2014.

e. Menghitung total kebutuhan waktu pada tiap operasi

Total kebutuhan waktu pada tiap operasi adalah waktu baku operasi tersebut dikalikan total kebutuhan komponen.

f. Penjadwalan dengan metode perusahaan

Dalam hal ini penjadwalan yang digunakan diperusahaan adalah diurutkan berdasar job yang mempunyai total waktu paling lama.

g. Penjadwalan dengan algoritma jadwal non delay.

Tahap dalam melakukan penjadwalan dengan menggunakan algoritma jadwal non delay dapat dilihat pada II A.

h. Perbandingan hasil penjadwalan

Dalam penelitian ini yang dibandingkan adalah makespan yang dihasilkan oleh masing-masing metode penjadwalan.

\section{F. Kesimpulan}

Penyimpulan hasil penelitian dikarenakan dalam penelitian ini perumusan masalahnya untuk meminimalkan makespan maka kesimpulanya adalah selisih waktu antara metode penjadwalan yang digunakan oleh perusahaan dengan usulan penjadwalan yang dibuat. 


\section{HASIL DAN PEMBAHASAN}

\section{A. Pengumpulan Data}

Produk yang dipesan pada bulan Desember 2014 ditunjukan pada tabel 1.

Tabel 1. Data Produk yang dipesan

\begin{tabular}{llccl} 
No & \multicolumn{1}{c}{ Kode Produk } & $\begin{array}{c}\text { Jumlah order } \\
\text { (unit) }\end{array}$ & Jenis kayu & Tanggal order \\
\hline 1 & ED-01 + Kusen gundul & 25 & Jati & 12 Desember 2014 \\
\hline 2 & $\begin{array}{l}\text { ED-23 RM + kusen } \\
\text { gundul }\end{array}$ & 40 & Jati & 14 Desember 2014 \\
\hline 3 & E-24 + kusen gundul & 30 & Jati & 17 Desember 2014 \\
\hline 4 & ED-04 + kusen gundul & 35 & Jati & 20 Desember 2014 \\
\hline 5 & Pst-1 & 20 & Jati & 22 Desember 2014 \\
\hline 6 & Pk1-04 + kusen gundul & 15 & Jati & 23 Desember 2014 \\
\hline & & & &
\end{tabular}

Setelah diketahui apa saja produk yang dipesan, karena dalam penelitian ini job adalah komponen dari produk tersebut maka untuk mengetahui komponen yang dibutuhkan dilihat pada struktur produk setiap produk yang dipesan. Berikut adalah daftar komponen untuk memenuhi order pada bulan Desember 2014 berserta mesin yang dilewati dalam pembuatanya ditunjukan pada tabel 2 .

Tabel 2. Daftar komponen dan urutan mesin yang dilewati

\begin{tabular}{|c|c|c|c|c|c|c|c|c|c|}
\hline \multirow{2}{*}{ No } & \multirow{2}{*}{$\begin{array}{c}\text { Kode } \\
\text { Komponen }\end{array}$} & \multirow{2}{*}{$\begin{array}{c}\text { Kode } \\
\text { Job }\end{array}$} & \multicolumn{7}{|c|}{ Operasi } \\
\hline & & & O-1 & $\mathrm{O}-2$ & O-3 & $\mathrm{O}-4$ & O-5 & O-6 & O-7 \\
\hline 1 & A-1 & JOB-1 & M-1 & M-2 & M-3 & M-6 & M-7 & & \\
\hline 2 & A-3 & JOB-2 & M-1 & M-2 & M-4 & M-6 & M-7 & & \\
\hline 3 & A-6 & JOB-3 & M-1 & M-2 & M-4 & M-6 & M-7 & & \\
\hline 4 & B-1 & JOB-4 & M-1 & M-2 & M-4 & M-6 & M-7 & & \\
\hline 5 & B-2 & JOB-5 & M-1 & M-2 & M-4 & M-3 & M-6 & M-7 & \\
\hline 6 & AT-1 & JOB-6 & M-1 & M-2 & M-5 & M-4 & M-6 & M-7 & \\
\hline 7 & AT-2 & JOB-7 & M-1 & M-2 & M-5 & M-4 & M-3 & M-6 & M-7 \\
\hline 8 & AT-3 & JOB-8 & M-1 & M-2 & M-4 & M-6 & M-7 & & \\
\hline 9 & AT-4 & JOB-9 & M-1 & M-2 & M-4 & M-3 & M-6 & M-7 & \\
\hline 10 & $\mathrm{~T}-1$ & JOB-10 & M-1 & M-2 & M-4 & M-6 & M-7 & & \\
\hline 11 & $\mathrm{~T}-2$ & JOB-11 & M-1 & M-2 & M-4 & M-6 & M-7 & & \\
\hline 12 & D-1 & JOB-12 & M-1 & M-2 & M-8 & M-6 & & & \\
\hline 13 & D-2 & JOB-13 & M-1 & M-2 & M-8 & M-6 & & & \\
\hline 14 & D-3 & JOB-14 & M-1 & M-2 & M-8 & M-6 & & & \\
\hline 15 & D-4 & JOB-15 & M-1 & M-2 & M-8 & M-6 & & & \\
\hline 16 & D-5 & JOB-16 & M-1 & M-2 & M-5 & M-8 & M-6 & & \\
\hline 17 & D-6 & JOB-17 & M-1 & M-2 & M-5 & M-8 & M-6 & & \\
\hline
\end{tabular}




\begin{tabular}{llllllll}
\hline 18 & K-1 & JOB-18 & M-1 & M-2 & M-9 & M-4 & M-6 \\
\hline 19 & K-2 & JOB-19 & M-1 & M-2 & M-9 & M-3 & M-6 \\
\hline
\end{tabular}

\section{B. Total Kebutuhan Waktu Pada Tiap Operasi}

Total kebutuhan waktu pada tiap operasi adalah waktu baku operasi tersebut dikalikan kebutuhan komponen dibagi jumlah mesin yang tersedia. Contoh untuk total kebutuhan waktu operasi 1 pada JOB-1 adalah $(3,68$ menit x 275)/2 $=530,75$ menit atau 8,85 jam. Total kebutuhan waktu pada tiap operasi dapat dilihat pada tabel 3 .

Tabel 3. Matrix total waktu yang dibutuhkan pada tiap operasi

\begin{tabular}{|c|c|c|c|c|c|c|c|c|}
\hline \multirow{2}{*}{ No } & \multirow{2}{*}{$J o b$} & \multicolumn{7}{|c|}{ Operasi (jam) } \\
\hline & & $\mathrm{O}-1$ & $\mathrm{O}-2$ & $\mathrm{O}-3$ & $\mathrm{O}-4$ & O-5 & O-6 & O-7 \\
\hline 1 & JOB-1 & 8,85 & 15,06 & 50,72 & 6,69 & 16,23 & & \\
\hline 2 & JOB-2 & 2,01 & 3,57 & 16,38 & 1,98 & 4,63 & & \\
\hline 3 & JOB-3 & 1,38 & 2,28 & 11,09 & 0,89 & 2,09 & & \\
\hline 4 & JOB-4 & 1,81 & 2,23 & 11,91 & 0,86 & 2,12 & & \\
\hline 5 & JOB-5 & 1,92 & 2,37 & 12,65 & 4,97 & 1,17 & 2,62 & \\
\hline 6 & JOB-6 & 1,28 & 1,87 & 2,53 & 8,56 & 0,80 & 1,75 & \\
\hline 7 & JOB-7 & 1,28 & 1,73 & 2,53 & 8,56 & 3,58 & 0,77 & 1,71 \\
\hline 8 & JOB-8 & 0,69 & 0,68 & 3,84 & 0,20 & 0,59 & & \\
\hline 9 & JOB-9 & 0,83 & 0,83 & 4,61 & 3,75 & 0,30 & 0,85 & \\
\hline 10 & JOB-10 & 1,48 & 1,98 & 8,19 & 1,22 & 3,05 & & \\
\hline 11 & JOB-11 & 2,09 & 3,12 & 16,75 & 1,87 & 4,48 & & \\
\hline 12 & JOB-12 & 1,44 & 3,84 & 2,36 & 0,79 & & & \\
\hline 13 & JOB-13 & 2,01 & 5,92 & 4,02 & 1,32 & & & \\
\hline 14 & JOB-14 & 2,52 & 7,21 & 5,05 & 1,62 & & & \\
\hline 15 & JOB-15 & 2,73 & 4,35 & 5,56 & 2,20 & & & \\
\hline 16 & JOB-16 & 0,98 & 2,87 & 1,22 & 1,98 & 0,60 & & \\
\hline 17 & JOB-17 & 0,90 & 2,76 & 1,03 & 2,07 & 0,69 & & \\
\hline 18 & JOB-18 & 9,57 & 17,77 & 32,92 & 29,19 & 9,21 & & \\
\hline 19 & JOB-19 & 4,33 & 7,24 & 13,87 & 20,50 & 3,62 & & \\
\hline
\end{tabular}




\section{Penjadwalan Produksi Menggunakan Metode Perusahaan}

Penjadwalan produksi yang diterapkan di perusahaan adalah diurutkan berdasar komponen atau job yang mempunyai total waktu proses terlama sampai yang terkecil. Total waktu pembuatan adalah jumlah dari seluruh operasi dalam pembuatan komponen tersebut contoh: total waktu proses job-1 adalah O-1 + O-2+ O-3 + O-4 + O-5 = 8,85 + $15,06+50,72+6,69+16,23=97,55$ jam. Sehingga aturan penjadwalan di Perusahaan menghasilkan urutan pengerjaan job sebagai berikut: JOB-18, JOB-1, JOB-19, JOB-2, JOB-11, JOB-5, JOB-4, JOB-3, JOB-7, JOB-14, JOB-10, JOB-6, JOB-15, JOB-13, JOB-9, JOB-12, JOB-16, JOB-17, JOB-8. Gant chart hasil penjadwalan perusahaan dapat dilihat pada gambar 2 .

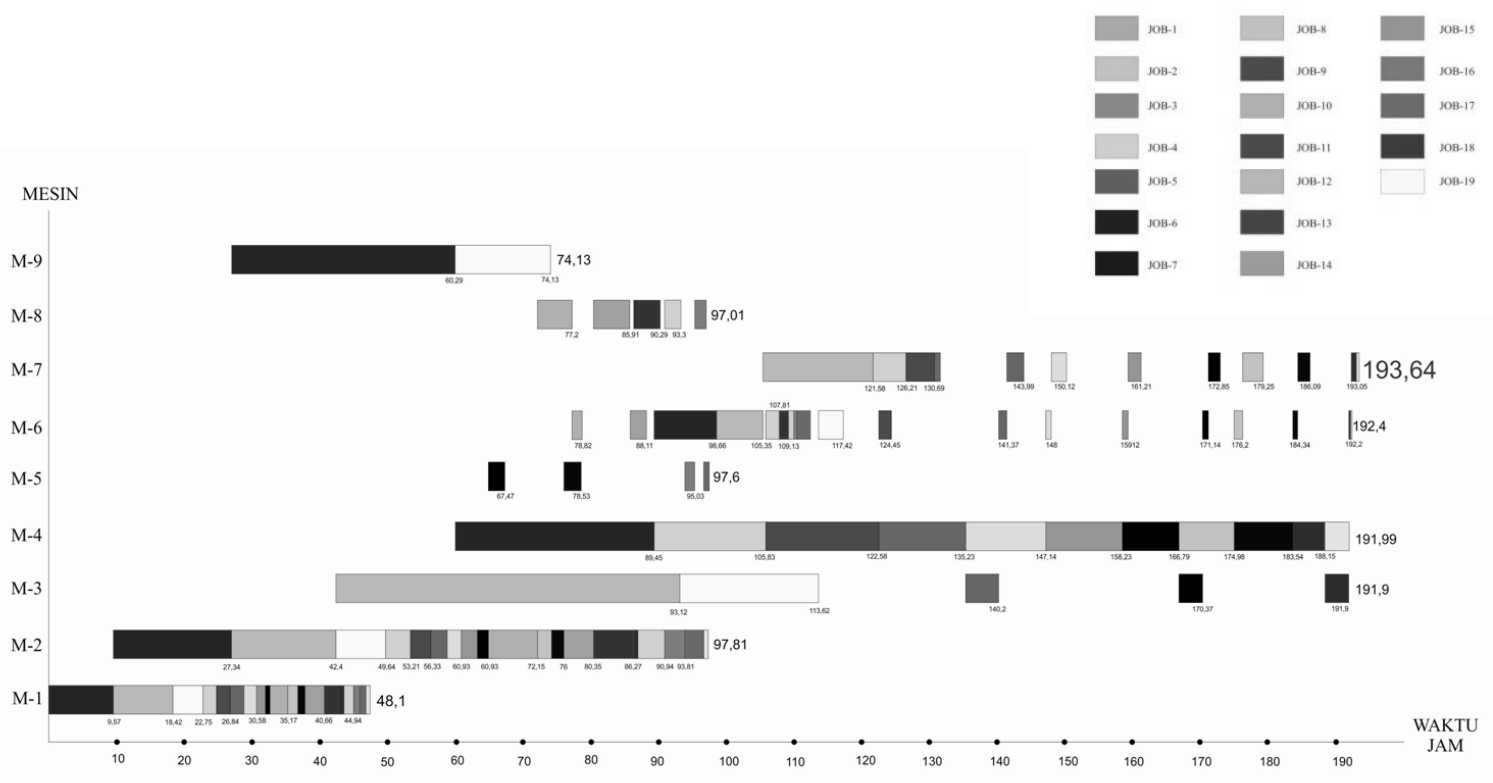

Gambar 1. Gant chart penjadwalan dengan metode perusahaan

Dilihat dari gambar 2 makespan dari penjadwalan perusahaan adalah 193,64 jam yang merupakan waktu penyelesaian pada mesin 7 .

D. Penjadwalan dengan Menggunakan Algoritma Jadwal Non Delay

Penjadwalan produksi dengan menggunakan algoritma jadwal non delay dimulai dengan membuat triplet waktu pada tiap operasi $\left(p_{i j k}\right)$, kemudian menjadwalkan dengan langkah seperti pada landasan teori II A, hasil penjadwalan ditunjukan pada tabel 4. 
Tabel 4. Penjadwalan dengan menggunakan algoritma jadwal Non-delay

\begin{tabular}{|c|c|c|c|c|c|c|c|c|c|c|c|c|c|c|c|c|}
\hline \multirow{2}{*}{$\mathrm{K}$} & \multicolumn{9}{|c|}{ Mesin } & \multirow{2}{*}{$\mathrm{S}(\mathrm{k})$} & \multirow{2}{*}{$\mathrm{Sj}$} & \multirow{2}{*}{$\begin{array}{c}\mathrm{Tij} \\
(\mathrm{jam})\end{array}$} & \multirow{2}{*}{$\begin{array}{c}\mathrm{fj} \\
(\mathrm{jam})\end{array}$} & \multirow{2}{*}{$\begin{array}{c}\mathrm{S}^{*} \\
(\mathrm{jam})\end{array}$} & \multirow{2}{*}{$\mathrm{m}^{*}$} & \multirow{2}{*}{ PS(k) } \\
\hline & 1 & 2 & 3 & 4 & 5 & 6 & 7 & 8 & 9 & & & & & & & \\
\hline \multirow[t]{19}{*}{1} & 0 & 0 & 0 & 0 & 0 & 0 & 0 & 0 & 0 & $\mathrm{P}_{111}$ & 0 & 8,85 & 8,85 & 0 & 1 & $\mathrm{P}_{811}$ \\
\hline & & & & & & & & & & $\mathrm{P}_{211}$ & 0 & 2,01 & 2,01 & & & \\
\hline & & & & & & & & & & $P_{311}$ & 0 & 1,38 & 1,38 & & & \\
\hline & & & & & & & & & & $\mathrm{P}_{411}$ & 0 & 1,81 & 1,81 & & & \\
\hline & & & & & & & & & & $P_{511}$ & 0 & 1,92 & 1,92 & & & \\
\hline & & & & & & & & & & $\mathrm{P}_{611}$ & 0 & 1,28 & 1,28 & & & \\
\hline & & & & & & & & & & $P_{711}$ & 0 & 1,28 & 1,28 & & & \\
\hline & & & & & & & & & & $P_{811}$ & 0 & 0,69 & 0,69 & & & \\
\hline & & & & & & & & & & $P_{911}$ & 0 & 0,83 & 0,83 & & & \\
\hline & & & & & & & & & & $\mathrm{P}_{1011}$ & 0 & 1,48 & 1,48 & & & \\
\hline & & & & & & & & & & $\mathrm{P}_{1111}$ & 0 & 2,09 & 2,09 & & & \\
\hline & & & & & & & & & & $\mathrm{P}_{1211}$ & 0 & 1,44 & 1,44 & & & \\
\hline & & & & & & & & & & $\mathrm{P}_{1311}$ & 0 & 2,01 & 2,01 & & & \\
\hline & & & & & & & & & & $\mathrm{P}_{1411}$ & 0 & 2,52 & 2,52 & & & \\
\hline & & & & & & & & & & $\mathrm{P}_{1511}$ & 0 & 2,73 & 2,73 & & & \\
\hline & & & & & & & & & & $\mathrm{P}_{1611}$ & 0 & 0,98 & 0,98 & & & \\
\hline & & & & & & & & & & $\mathrm{P}_{1711}$ & 0 & 0,90 & 0,90 & & & \\
\hline & & & & & & & & & & $\mathrm{P}_{1811}$ & 0 & 9,57 & 9,57 & & & \\
\hline & & & & & & & & & & $\mathrm{P}_{1911}$ & 0 & 4,33 & 4,33 & & & \\
\hline \multirow[t]{20}{*}{2} & 0,69 & 0 & 0 & 0 & 0 & 0 & 0 & 0 & 0 & $\mathrm{P}_{111}$ & 0,69 & 8,85 & 8,85 & 0,69 & 1,2 & $\begin{array}{l}\mathrm{P}_{911}, \\
\mathrm{P}_{822}\end{array}$ \\
\hline & & & & & & & & & & $\mathrm{P}_{211}$ & 0,69 & 2,01 & 2,01 & & & \\
\hline & & & & & & & & & & $\mathrm{P}_{311}$ & 0,69 & 1,38 & 1,38 & & & \\
\hline & & & & & & & & & & $\mathrm{P}_{411}$ & 0,69 & 1,81 & 1,81 & & & \\
\hline & & & & & & & & & & $\mathrm{P}_{511}$ & 0,69 & 1,92 & 1,92 & & & \\
\hline & & & & & & & & & & $\mathrm{P}_{611}$ & 0,69 & 1,28 & 1,28 & & & \\
\hline & & & & & & & & & & $\mathrm{P}_{711}$ & 0,69 & 1,28 & 1,28 & & & \\
\hline & & & & & & & & & & $\mathrm{P}_{822}$ & 0,69 & 0,68 & 1,37 & & & \\
\hline & & & & & & & & & & $\mathrm{P}_{911}$ & 0,69 & 0,83 & 1,52 & & & \\
\hline & & & & & & & & & & $\mathrm{P}_{1011}$ & 0,69 & 1,98 & 1,98 & & & \\
\hline & & & & & & & & & & $\mathrm{P}_{1111}$ & 0,69 & 3,12 & 3,12 & & & \\
\hline & & & & & & & & & & $\mathrm{P}_{1211}$ & 0,69 & 3,84 & 3,84 & & & \\
\hline & & & & & & & & & & $\mathrm{P}_{1311}$ & 0,69 & 5,92 & 5,92 & & & \\
\hline & & & & & & & & & & $\mathrm{P}_{1411}$ & 0,69 & 7,21 & 7,21 & & & \\
\hline & & & & & & & & & & $\mathrm{P}_{1511}$ & 0,69 & 4,35 & 4,35 & & & \\
\hline & & & & & & & & & & $\mathrm{P}_{1611}$ & 0,69 & 2,87 & 2,87 & & & \\
\hline & & & & & & & & & & $P_{1711}$ & 0,69 & 2,76 & 2,76 & & & \\
\hline & & & & & & & & & & $\mathrm{P}_{1811}$ & 0,69 & 17,77 & 17,77 & & & \\
\hline & & & & & & & & & & $\mathrm{P}_{1911}$ & 0,69 & 7,24 & 7,24 & & & \\
\hline & & & & & & & & & & $\ldots \ldots \ldots$ & $\ldots \ldots \ldots$ & ............ & ........... & & & \\
\hline$\ldots$ & $\ldots \ldots \ldots$ & $\ldots \ldots \ldots .$. & $\ldots \ldots \ldots \ldots$ & ............. & ........... & $\ldots \ldots \ldots . .$. & $\ldots \ldots \ldots . .$. & $\ldots \ldots \ldots$ & $\ldots \ldots \ldots$ & $\ldots \ldots \ldots$ & $\ldots \ldots \ldots$ & ........... & $\ldots \ldots .$. & $\ldots \ldots \ldots$ & $\ldots \ldots$ & $\ldots \ldots .$. \\
\hline \multirow[t]{2}{*}{74} & 48,1 & 87,45 & 145,87 & 149,45 & 17,46 & 152,56 & 110,35 & 52,43 & 120,37 & $\mathrm{P}_{157}$ & 152,56 & 16,23 & 168.79 & 15,26 & 6,7 & $\mathrm{P}_{157}$ \\
\hline & & & & & & & & & & $\mathrm{P}_{1856}$ & 152,56 & 9,21 & 161.77 & & & $P_{1856}$ \\
\hline 75 & 48,1 & 87,45 & 145,87 & 149,45 & 17,46 & 161,77 & 168,79 & 52,43 & 120,37 & & & & & & & \\
\hline
\end{tabular}


Dari penjadwalan manual dengan algoritma jadwal non delay pada tabel 4 makespan yang dihasilkan adalah 168,79 jam atau 22 hari kerja. Gant chart dari penjadwalan dengan algoritma jadwal non delay dapat dilihat pada gambar 3.

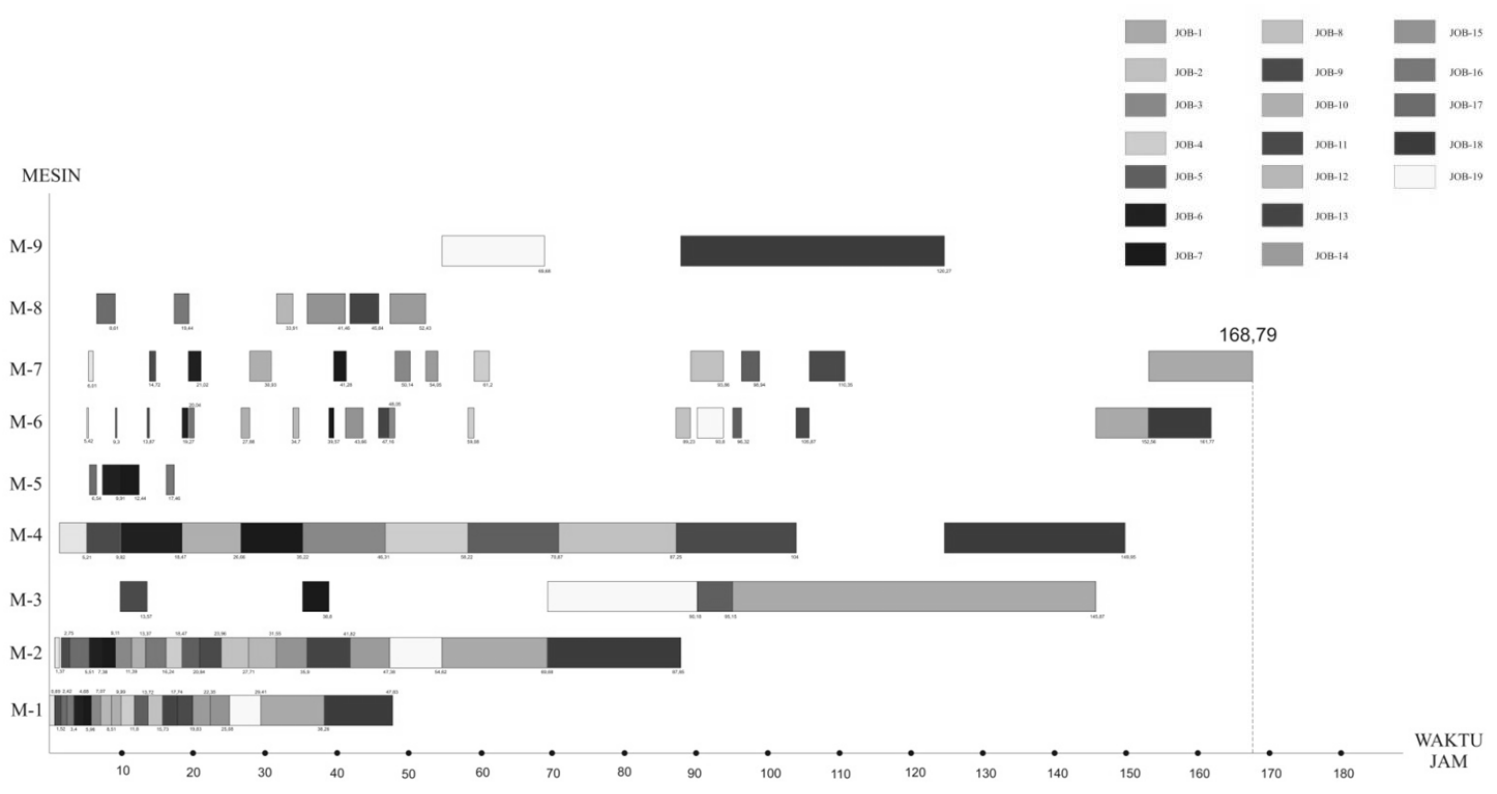

Gambar 3. Gant chart penjadwalan produksi dengan menggunakan algoritma jadwal non delay

Rincian penyelesaian pengerjaan job pada tiap mesin dari gant chart pada gambar 3 adalah sebagai berikut:
a. M-1 dengan waktu penyelesaian 48,1 jam
b. M-2 dengan waktu penyelesaian 87,45 jam
c. M-3 dengan waktu penyelesaian 145,87 jam
d. M-4 dengan waktu penyelesaian 149,45 jam
e. M-5 dengan waktu penyelesaian 17,46 jam
f. M-6 dengan waktu penyelesaian 161,77 jam
g. M-7 dengan waktu penyelesaian 168,79 jam
h. M-8 dengan waktu penyelesaian 52,43 jam
i. M-9 dengan waktu penyelesaian 120,37 jam

\section{E. Perbandingan Hasil Penjadwalan}

Makespan dari penjadwalan produksi yang digunakan di perusahaan adalah 193,64 jam atau 25 hari kerja sedangkan makespan dari usulan penjadwalan adalah 168,79 jam atau 22 hari kerja, dengan demikian usulan penjadwalan produksi yang diajukan dapat menghemat waktu produksi sebesar 24,85 jam atau 3 hari kerja lebih 0,85 jam.

\section{KESIMPULAN}

1. Urutan pengerjaan job yang didapatkan dari penjadwalan dengan algoritma jadwal non delay adalah sebagai adalah seperti berikut:

- M-1 : JOB-8, JOB-9, JOB-17, JOB-16, JOB-6, JOB-7, JOB-3, JOB-12, JOB-10, JOB-4, JOB-5, JOB-2, JOB-13, JOB-11, JOB-14, JOB-15, JOB-19, JOB-1, JOB-18

- M-2 : JOB-8, JOB-9, JOB-17, JOB-6, JOB-7, JOB-3, JOB-10, JOB-16, JOB-4, JOB-5, JOB-11, JOB-2, JOB-12, JOB-15, JOB-13, JOB-14, JOB-19, JOB-1, JOB-18

- M-3 : JOB-9 JOB-7, JOB-19, JOB-5, JOB-1 
- M-4 : JOB-8, JOB-9, JOB-6, JOB-10, JOB-7, JOB-3, JOB-4, JOB-5, JOB-2, JOB$11, \mathrm{JOB}-18$

- M-5 : JOB-17, JOB-6, JOB-7, JOB-16

- M-6 : JOB-8, JOB-17, JOB-9, JOB-6, JOB-16, JOB-10, JOB-12, JOB-7, JOB-5, JOB-13, JOB-3, JOB-14, JOB-4, JOB-2, JOB-19, JOB-5, JOB-11, JOB-1, JOB-18

- M-7 : JOB-8, JOB-9, JOB-6, JOB-10, JOB-7, JOB-3, JOB-4, JOB-2, JOB-5, JOB$11, \mathrm{JOB}-1$

- M-8 : JOB-17, JOB-16, JOB-12, JOB-15, JOB-13, JOB-14

- M-9 : JOB-19, JOB-18

2. Perbandingan makespan usulan penjadwalan dengan aturan penjadwalan yang digunakan di perusahaan menunjukan makespan dari usulan penjadwalan dapat menghemat waktu sebesar 24,85 jam atau $12,83 \%$, dan jika dihitung berdasarkan hari kerja usulan penjadwalan dapat menghemat 3 hari lebih 0,85 jam.

\section{DAFTAR PUSTAKA}

[1] Fitri, Prima \& Ramawinta, Fitri 2013, Penjadwalan Mesin Dengan Menggunakan Algoritma Pembangkit Jadwal Aktif Dan Algoritma Jadwal Non DelayUntuk Produk Hidrotiller dan Hammermil pada CV. Cheery Sarana Agro,Jurnal Optimasi Sistem Industri, Vol. 12 No. 2

[2] Ginting, R 2009, Penjadwalan mesin, Yogyakarta : Graha Ilmu.

[3] Baker, Keneth, R \& Trietsch 2009, Principles of Squencing and scheduling, John Wiley \& Sons, Inc 